\title{
NEW NORMAL "INDONESIA" AFTER COVID-19 PANDEMIC
}

\author{
ANDRIA PRAGHOLAPATI \\ Nursing Department, Faculty of Sport Education and Health Science, Universitas Pendidikan Indonesia \\ Email: Andria.pragholapati@upi.edu
}

\begin{abstract}
Corona Virus 2019 (COVID-19) which hit Indonesia is very important for all major aspects of health and economy. The Indonesian government in its fight against COVID-19 was carried out in various ways contained in government regulations. At present the government rules against COVID-19 and the renewal that took place in Indonesia, the Indonesian government issued a New Normal. The purpose of this review is to bring out a new normal term in Indonesia after the COVID-19 pandemic. In conclusion, New Normal is a term resulting from the adaptation process while in the COVID-19 pandemic. Humans will have new habits from the learning process and the adaptation process after the COVID-19 pandemic.
\end{abstract}

Keywords: New normal, Covid-19, Pandemic, Corona Virus, Indonesia

\section{INTRODUCTION}

The World Health Organization (WHO) has declared the Corona Virus Disease 2019 (COVID19) to be a pandemic [1] - [4]. COVID-19 cases in Indonesia are now increasingly widespread in various regions of Indonesia, seen from the increasing number of cases and the number of deaths due to COVID-19. The impact of COVID-19 in Indonesia on all aspects, namely political, economic, social, cultural, defense and security aspects, as well as the welfare of the people in Indonesia. The Government of Indonesia stipulates the Corona Virus Disease 2019 (COVID-19) Public Health Emergency in Indonesia, which must be implemented in accordance with the provisions of the legislation. 


\section{RESULT AND DISCUSSION}

The Government of Indonesia in accordance with government regulation number 21 of 2020 concerning large-scale social restrictions in the framework of accelerating the handling of corona virus disease 2019 (COVID-19) has stated that large-scale social restrictions (PSBB) are carried out one of them by dismissing the workplace. limitation may be carried out in the long run because it will have an impact on the economy that must keep spinning, for that the Indonesian government makes efforts to mitigate and workplace readiness as optimal as possible so that it can adapt through changes in lifestyle in the COVID-19 (New Normal) situation. New Normal with Mitigation are actions to reduce or minimize the impact of a disaster on the community, especially the impact of COVID-19.

Indonesia is preparing to enter a new normal era where people can move outside the home in the midst of the Covid-19 corona virus outbreak. The only surefire way to handle Covid-19 that can be done to fight the Covid-19 pandemic before a vaccine is discovered is to adopt a normal lifestyle in a new (new normal) way. Until now, experts around the world are still working hard to really understand about this virus. So that you can then find the selected drug and vaccine that can be used to bring about immunity. As long as these efforts have not produced results or have not gotten the best results that can be agreed to be used throughout the world, the only way we can do is to guard against getting infected, to avoid contracting this disease and the public can use the covid-19 tracking application [5].

The government is preparing steps to implement new or normal conditions amid the highest increase in cases of Covid-19 infection in one day which reached 973 cases (5/21). However, a number of provinces, whose districts / cities have been referred to by the Covid Task Force 19 as green zones or without cases of infection, say the new normal protocol cannot be implemented in their region given the high number of cases. What are the new normal provisions? Monoarfa said that under normal new conditions, everyone must use a mask, hand sanitizer, and also wash their hands with soap. Then, physical restrictions will also be carried out. "Businesses have work guides from home. Restrictions on the workplace. If possible, we can make a video tutorial for every workplace," he said. In his presentation, the protocol at the central and local government 
level, among others, is the implementation of paid sick leave schemes and public campaigns on health protocols in public places, such as airports, schools, theaters, and sports facilities. Regarding massive tests, the government, through Bappenas, acknowledges that until now the number of tests per one million people in Indonesia is still very low, namely 743 tests (data 19/05). This figure is far below Thailand with 4,000 tests and Malaysia with 14,000 tests per one million people [6]

Decree of the Minister of Health of the Republic of Indonesia Number HK.01.07 / MENKES / 328/2020 concerning guidelines for preventing and controlling corona virus disease 2019 (covid19 ) in office and industry workplaces in supporting business continuity in a pandemic situation. In the guide, among others requires that the company has a separate area or room for employees who are suspected of having symptoms (people with symptoms) with corona virus. Workplaces are also encouraged to have resources that facilitate quarantine or independent isolation for employees. Companies must continue to provide the rights of employees who are undergoing quarantine or independent isolation even after the PSBB ends.

Decree of the Minister of Health of the Republic of Indonesia Number HK.01.07 / MENKES / 328/2020 concerning guidelines for preventing and controlling corona virus disease 2019 (covid19) in office and industry workplaces in supporting business continuity in a pandemic situation. Facilitating a safe and healthy workplace that is a) hygiene and sanitation of the work environment, b) hand washing facilities, c) Physical Distancing in all work activities, d) campaigning for a healthy living community movement (GERMAS) through healthy living patterns and clean living behaviors and healthy (PHBS) at work.

According to Amien Rais, the Indonesian version of The New Normal can actually be seen from the deteriorating social and economic conditions, such as the amount of unemployment which is inflated and the mounting state debt. What has been informed by the government about the implementation of new normal when the Covid-19 pandemic is different from the true meaning. Because there are no standards and norms that become a reference for the application of new normal. "So what is said is actually not new normal, but that we have to be straight normal forever and we continue that normal forever," he said 
"Because normally there are standards, there are norms, there are regular patterns, and of course there are reference points, this is not there at all," Amien added.

Nevertheless, Amien understood the government's intention to implement the new normal during the pandemic. He interpreted the government's intentions as a mechanism for the work of civil servants during a health emergency caused by Covid-19. "New is normal after the virus has subsided, that is, civil servants still wear masks, keep their distance, there are times at home, there are times at the office, and so on," he said [7].

Will everything return to normal? Are there things that we are doing now that will be part of the "new normal"? The answer to the first question is almost certainly no. Covid-19 pandemic will be one dichotomous event that divides life into before and after. We live through them, learn from them, and adapt. The answer to the second question, for good reason, is almost certainly yes - and not just practice with high reliability for behaviors such as hand hygiene. We are actively redesigning the way we provide care to do what is best for our patients during this crisis. Some aspects of the redesign are likely to last after the crisis has passed [8].

We are actively redesigning the way we provide care to do what is best for our patients during this crisis. Some aspects of the redesign are likely to last after the crisis has passed. We learned new skills during this crisis because we treated patients without seeing them in the office. These skills will make treatment better, more comfortable, and more affordable after the pandemic ends [8]. We must focus first on finding out how to provide the best treatment, which he thinks is difficult. Only after that, he said, should we worry about how to be paid for it. Crisis like the Covid-19 pandemic forces us to take wisdom [8].

Workplaces and social responsibility continue to be advocated. Posters and videos showing proper hand hygiene techniques and wearing and removing personal protective equipment are clearly visible in the staff area of our division and posted on our intranet. If people are sick, those who are sick are advised to stay at home and avoid social activities. Because we have separated into smaller functional teams at work, minimal mixing with partner teams at rest and after work is important for the concept of separating our workforce to be useful. Safe exploration, defined at least $1 \mathrm{~m}$ apart, both inside and outside the workplace is known to reduce the likelihood of spread of pathogens. In line with published recommendations, we have instituted mandatory 
temperature reporting via a secure web link from all our staff twice a day, 7 days a week, using a thermometer released by the hospital [9]

As the COVID-19 situation continues to evolve, we will continue to survive and hope that the concepts we introduce will enable us to control and adapt quickly to situations that occur. It is possible that this pandemic can become a new normative state, and we may have to develop new infection control standards so that operations can continue with minimal risk for staff and patients. At the time of writing (March 26, 2020), we had 35 confirmed COVID-19 cases in our hospital, 9 of which had been safely discharged, 1 was moved, and 25 were left in the isolation unit; no intra-hospital transmission to health workers occurred. Our experience over the past 9 weeks can help shape the response of other radiological services during the rapidly developing global pandemic COVID-19 [9].

Preventing the transmission of infectious diseases to patients and protecting health care workers must be a top priority every day, especially but not exclusively during recurrent viral epidemics [10]. Whether our hospital is ready enough to face a pandemic or not is open to question. Getting adequate supplies such as N95 masks, powered air-purifying respirators, and other protective equipment to deal with significant outbreaks of infectious diseases may be difficult. Hospitals often utilize "timely" supply chain practices that are very vulnerable to disruptions, and shortages are common in ordinary circumstances, especially during pandemics. Guidance is available on how to optimize the use of respirators among health care workers during national shortages. We believe that infection prevention is an important function of our health care system. Hospitals and health care workers must always practice infection prevention in routine daily patient care and must be prepared and trained to negotiate epidemics that are sure to be repeated regularly. COVID-19 is just the latest example of the need for constant vigilance [10].

\section{REFERENCES}

[1] A. Pragholapati, “Mental Health in pandemic,” pp. 1-7, 2020.

[2] A. Pragholapati, “COVID-19 IMPACT ON STUDENTS,” 2020.

[3] A. Pragholapati, “RESILIENSI PADA KONDISI WABAH COVID-19.,” 2020.

[4] A. Pragholapati, "Self-Efficacy Of Nurses During The Pandemic Covid-19," no. May 
2020, p. 2020.

[5] “RI Bersiap Terapkan New Normal, Ini Aplikasi Lacak Covid-19." [Online]. Available: https://www.cnbcindonesia.com/tech/20200525103809-37-160672/ri-bersiap-terapkannew-normal-ini-aplikasi-lacak-covid-19. [Accessed: 25-May-2020].

[6] 'Covid-19: Pemerintah siapkan skenario 'new normal', sejumlah daerah nyatakan 'belum siap, pusat harus lihat fakta lapangan' - BBC News Indonesia." [Online]. Available: https://www.bbc.com/indonesia/indonesia-52661832. [Accessed: 25-May-2020].

[7] “Amien Rais Jabarkan Definisi The New Normal Versi Indonesia." [Online]. Available: https://www.cnnindonesia.com/nasional/20200525154519-20-506745/amien-raisjabarkan-definisi-the-new-normal-versi-indonesia. [Accessed: 25-May-2020].

[8] T. H. Lee, "Innovations in Care Creating the New Normal: The Clinician Response to Covid-19," NEJM Catal., 2020.

[9] R. C. Chen, T. Tong Tan, and L. P. Chan, "Adapting to a new normal? 5 key operational principles for a radiology service facing the COVID-19 pandemic."

[10] A. Bowdle and L. S. Munoz-Price, "Preventing Infection of Patients and Healthcare Workers Should Be the New Normal in the Era of Novel Coronavirus Epidemics," Anesthesiology, vol. 132, no. 6, pp. 1292-1295, Jun. 2020. 